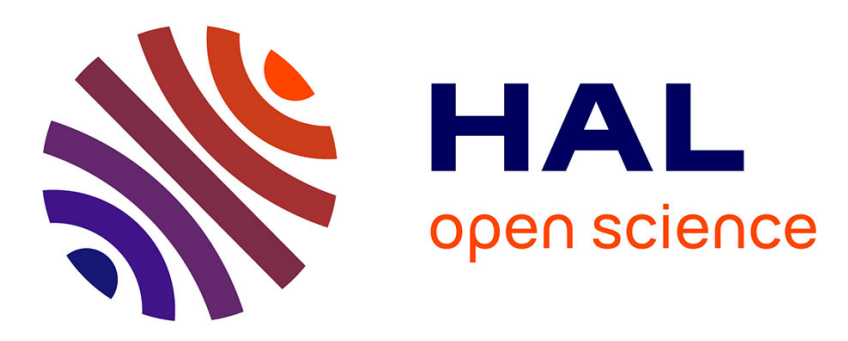

\title{
Influence of anthropogenic sources on total gaseous mercury variability in Grenoble suburban air (France)
}

Aurélien Dommergue, Christophe P. Ferrari, Frédéric Planchon, Claude F.

Boutron

\section{- To cite this version:}

Aurélien Dommergue, Christophe P. Ferrari, Frédéric Planchon, Claude F. Boutron. Influence of anthropogenic sources on total gaseous mercury variability in Grenoble suburban air (France). Science of the Total Environment, 2002, 297, pp.203-213. hal-00001046

\section{HAL Id: hal-00001046 \\ https://hal.science/hal-00001046}

Submitted on 21 Jan 2004

HAL is a multi-disciplinary open access archive for the deposit and dissemination of scientific research documents, whether they are published or not. The documents may come from teaching and research institutions in France or abroad, or from public or private research centers.
L'archive ouverte pluridisciplinaire HAL, est destinée au dépôt et à la diffusion de documents scientifiques de niveau recherche, publiés ou non, émanant des établissements d'enseignement et de recherche français ou étrangers, des laboratoires publics ou privés. 


\title{
INFLUENCE OF ANTHROPOGENIC SOURCES ON TOTAL GASEOUS MERCURY VARIABILITY IN GRENOBLE SUBURBAN AIR (FRANCE)
}

\author{
Aurélien Dommergue ${ }^{1}$, Christophe P. Ferrari ${ }^{1,2, *}$, Frédéric A.M. Planchon ${ }^{1}$ and Claude F. \\ Boutron $^{1,3}$ \\ ${ }^{1}$ Laboratoire de Glaciologie et Géophysique de l' Environnement du CNRS, 54 rue Molière, BP 96, \\ 38402 Saint Martin d'Hères, France. \\ ${ }^{2}$ Institut des Sciences et Techniques de Grenoble, Université Joseph Fourier, 28 Avenue Benoît \\ Frachon, BP 53, 38041 Grenoble, France. \\ ${ }^{3}$ Unités de Formation et de Recherche de Mécanique et de Physique, Université Joseph Fourier \\ (Institut Universitaire de France), BP 68, 38041 Grenoble, France.
}

Corresponding author. Tel.: +334768242 00; fax: +33476824201

E-mail address: ferrari@glaciog.ujf-grenoble.fr

The Science of the Total Environment, in Press

\begin{abstract}
Total Gaseous Mercury (TGM) has been monitored at Champ sur Drac, a suburban site of Grenoble in southern east France. TGM measurements have been made over 4 periods of about 10 days throughout 1999-2000 using cold vapour atomic fluorescence absorption technique. The first monitoring campaign was initiated on November 4, 1999, followed by three other campaigns respectively on January 12, 2000, April 10, 2000 and July 17, 2000. Concurrent monitoring of $\mathrm{O}_{3}$, $\mathrm{NO}, \mathrm{NO}_{2}, \mathrm{SO}_{2}$ and of meteorological parameters have also been performed. The mean TGM concentration was $3.4 \mathrm{ng} \mathrm{m}^{-3}$ with maximum hourly mean concentration of $37.1 \mathrm{ng} \mathrm{m}^{-3}$. Although mean TGM concentration was not greatly different from those previously measured in the
\end{abstract}


troposphere, the greater TGM variability as well as the occurrence of high TGM concentration linked to particular wind conditions suggested the strong influence of anthropogenic sources. The chlor-alkali plant located nearby, the others chemical industries using fuel combustion and the municipal waste incinerator were thought to contribute to mercury pollution events.

Keywords: Total Gaseous Mercury; Atmosphere; Variability; France; Anthropogenic sources

\section{Introduction}

Since the pollution prevention concept emerged many years ago (Pacyna, 1986), there has been a growing concern about air quality in urban areas. To improve urban air quality, environmental policy makers expressed widespread interest in controlling and regulating major gaseous pollutants such as $\mathrm{O}_{3}, \mathrm{CO}, \mathrm{NO}, \mathrm{NO}_{2}, \mathrm{SO}_{2}$ and VOC (Volatile Organic Compounds). However gaseous mercury supervision is only from time to time included in urban pollution monitoring whereas the knowledge of its distribution and transport pathways are of critical importance. Enlarging air pollution monitoring program to atmospheric gaseous mercury survey can only ensure this.

Gaseous elemental mercury $\left(\mathrm{Hg}^{\circ}\right)$ is the dominant form $(\sim 98 \%$ e.g. Poissant, 2000$)$ of mercury in the atmosphere. Elemental mercury is very insoluble, unreactive (Schroeder and Munthe, 1998, Tokos et al., 1998) and thus has a residence time in the atmosphere of about 0.5-2 years (Lindqvist and Rodhe, 1985; Slemr et al., 1985; Munthe and McElroy, 1992). Therefore $\mathrm{Hg}^{\circ}$ is well mixed atmospherically and Total Gaseous Mercury (TGM) concentration is in the range $1-5 \mathrm{ng} \mathrm{m}^{-3}$ in the troposphere (Lee et al., 1998; Ebinghaus and Slemr, 2000; Urba et al., 2000).

Mercury is emitted into the atmosphere from a variety of natural and anthropogenic sources. The natural sources include volcanoes, crustal degassing, forests, lakes and oceans (Lindqvist and Rodhe, 1985, Mason et al., 1994), while fossil-fuel combustions, incineration, metallurgical processes and chlor-alkali plants constitute the largest part of anthropogenic $\mathrm{Hg}$ emissions (Pirrone 
et al., 1996). In French urban areas, waste incineration is the major source of $\mathrm{Hg}$ (CITEPA, 2000). The other contributions are coal combustion followed by chlor-alkali plants, wood combustion and metallurgic processes. Once emitted, mercury is involved in many physical and chemical transformations (Schroeder and Munthe, 1998; Lin and Pehkonen, 1999) and can be deposited by

wet and dry processes to environmental surfaces. These deposition processes are more efficient if mercury is in the +II oxidation state (Lindberg and Stratton, 1998).

Since information on background concentrations and anthropogenic sources are still lacking for many places in Europe, we present here the first automated long-term, high time resolution measurements of TGM concentration in France. To our knowledge, this report constitutes the first presentation of extended atmospheric mercury data from a site in France. We attempted to compare these data with other pollutants $\left(\mathrm{O}_{3}, \mathrm{NO}, \mathrm{NO}_{2}, \mathrm{SO}_{2}\right)$ concentrations and meteorological parameters (wind speed, wind direction, atmospheric pressure, temperature, solar irradiation and precipitation intensity). An assessment of potential anthropogenic mercury sources and their influence on our measurement site are also provided.

\section{Material and methods}

\subsection{Site characteristics}

TGM concentrations were determined in the vicinity of Grenoble in the south east of France (Fig. 1). The measurement station is located at Champ sur Drac $\left(45.080^{\circ} \mathrm{N}, 5.730^{\circ} \mathrm{E}, 267\right.$ meters a.s.1.) which is a suburban site of Grenoble, characterized by an industrial zone in the north and particularly a chlor-alkali plant (Fig. 2) using mercury cell process. Grenoble ( 400,000 inhabitants) is $\sim 10 \mathrm{~km}$ north from the site and has one of the largest municipal waste incinerator in the area. 


\subsection{Sampling and analysis}

TGM measurements were performed during four $\sim 10$-days campaigns. The first campaign was initiated on November 4, 1999. Others measurements followed respectively on January 12, 2000, April 10, 2000 and July 17, 2000.

Air samples were automatically collected outside with a Teflon line at 3 meters above the ground. We initiated routine measurements with an automated Gardis 1A+ analyser (Ekoservis, Lithuania) using the double amalgamation technique followed by Cold Vapour Atomic Absorption Spectrometry (C.V.A.A.S.). During each campaign TGM concentrations were measured every 15 minutes, 24 hours a day. The analyser, housed in air-conditioned shelter, was programmed to sample air at a flow rate of $11 \mathrm{~min}^{-1}$. Particulate matter was removed by $25-\mathrm{mm}$ diameter Teflon filter $(0.5 \mu \mathrm{m})$. The performances of the Gardis analyser for TGM monitoring have already been verified successfully through atmospheric measurements (Urba et al., 1995; Tan et al., 2000; Urba et al., 2000) and international intercomparison exercises (Ebinghaus et al., 1999; Munthe et al., 2001). Full details concerning accuracy and precision of our instrument can be found elsewhere (Ferrari et al., 2000) and calibration procedures and curves are given in Ferrari et al. (2001). A detection limit of about $0.1 \mathrm{ng} \mathrm{m}^{-3}$ was achieved.

Moreover concurrent monitoring, recorded every 15 minutes, of meteorological parameters (wind speed, wind direction, atmospheric pressure, temperature, solar irradiation and precipitation intensity) and of $\mathrm{O}_{3}, \mathrm{NO}, \mathrm{NO}_{2}, \mathrm{SO}_{2}$ facilitates the interpretation of $\mathrm{Hg}$ data.

\section{Results and discussion.}

\subsection{Annual, seasonal and diurnal variability of TGM}


A statistical summary of TGM data subdivided into their respective seasons is presented in Table 1. The mean seasonal TGM concentration varies throughout the year from $1.9 \mathrm{ng} \mathrm{m}^{-3}$ to $4.8 \mathrm{ng} \mathrm{m}^{-3}$. The mean TGM concentration (plus $1 \mathrm{SD})$ calculated over the year is $3.4 \pm 3.6 \mathrm{ng} \mathrm{m}^{-3}(\mathrm{~N}=3596)$. Maximum TGM concentration was recorded in July (45.9 $\mathrm{ng} \mathrm{m}^{-3}$ ) with an hourly mean concentration of $37.1 \mathrm{ng} \mathrm{m}^{-3}$ for this event.

Ozone mean concentrations are ranging from $\sim 7 \mathrm{ppbv}$ for winter data to $\sim 30 \mathrm{ppbv}$ for summer data with peaks up to $\sim 70$ ppbv. In southern Quebec, Poissant (1997) observed some evidence of chemical oxidation of TGM by ozone under high water vapour mixing ratio and ozone concentration higher than $30 \mathrm{ppbv}$. In Champ sur Drac, no significant correlation was noticed between TGM and ozone values. One cannot conclude that there is no oxidation of $\mathrm{Hg}^{\circ}$ by ozone. It rather confirms that this reaction is slow and that reactions in urban atmosphere are various and complex.

The average TGM concentration for each season as well as for the entire set of data are comparable to those typically measured in the troposphere (i.e. in the range $1-5 \mathrm{ng} \mathrm{m}^{-3}$, e.g. Lee $e t$ al., 1998; Ebinghaus and Slemr, 2000; Urba et al., 2000). Nevertheless, as regarding the temporal variability of 15 min TGM data (Fig. 3), one can notice that under particular wind conditions a strong influence of anthropogenic sources of Champ sur Drac and Grenoble is observed. Although low TGM concentrations (around $2 \mathrm{ng} \mathrm{m}^{-3}$ ) are the most recurrent, there are many peaks above 10 $\mathrm{ng} \mathrm{\textrm {m } ^ { - 3 }}$ in each campaign (approximately $10 \%$ of fall and summer data).

There are limited published data in France with which to compare our measurements. It is thus difficult to address a precise comparison regarding the $\mathrm{Hg}$ levels in French cities. Nonetheless, $\mathrm{Hg}^{\circ}$ has already been determined in a few air samples in Bordeaux (Pécheyran et al., 2000) using a different technique. They found mean $\mathrm{Hg}^{\circ}$ concentrations of $2.7 \mathrm{ng} \mathrm{m}^{-3}$ and $4.0 \mathrm{ng} \mathrm{m}^{-3}$ in open urban area and suburban sites respectively. However, the number of samples collected was limited and inadequate to discuss on TGM variability. 
On the other hand, several atmospheric TGM monitoring campaigns have been already achieved in the rest of the world. Measurements made in clean atmosphere have shown relatively similar pattern with concentration of the order of $1.5 \mathrm{ng} \mathrm{m}^{-3}$ and with a variability of low amplitude. Indeed, in the atmosphere over the southern Baltic Sea coast, Urba et al. (2000) reported mean TGM concentration of $1.37 \mathrm{ng} \mathrm{m}^{-3}$ and $1.94 \mathrm{ng} \mathrm{m}^{-3}$ (in the range $0.68-2.20 \mathrm{ng} \mathrm{m}^{-3}$ and $0.98-3.81 \mathrm{ng} \mathrm{m}^{-3}$ respectively). Schroeder et al. (1995), during the first winter cruise of the "Polarstern" from Germany to the Nordic Seas recorded a mean concentration of $1.47 \mathrm{ng} \mathrm{m}^{-3}\left(0.67-2.82 \mathrm{ng} \mathrm{m}^{-3}\right)$. Measurements performed at the summit of Wank mountain in Germany (Slemr and Scheel, 1998) showed data ranging from $1.80 \mathrm{ng} \mathrm{m}^{-3}$ to $3.77 \mathrm{ng} \mathrm{m}^{-3}$ with an annual mean of $1.82 \mathrm{ng} \mathrm{m}^{-3}$ for the year 1996. More recently a coordinated study in Europe showed mean TGM concentration in the range of 1.6-2.4 $\mathrm{ng} \mathrm{m}^{-3}$ in the Northern Europe and the Mediterranean area (Wängberg et al., 2001).

However Lee et al. (1998) mentioned a greater variability for measurements made closer to sources. It is well illustrated by measurements reported by Poissant (2000) around Montreal that show low TGM mean concentration with highly variable concentration. Although our mean TGM concentration is obviously higher owing to the proximity of strong $\mathrm{Hg}$ sources, our measurements reveal a similar pattern, since the variability and the amplitude of TGM concentrations are important. Nevertheless, we could expect a greater influence of anthropogenic sources with a higher mean TGM concentration. Indeed as we mentioned previously our measurement site is close to a chlor-alkali plant (less than $4 \mathrm{~km}$ ). Earlier studies conducted near chlor-alkali complex using LIDAR technique (Ferrara et al., 1992) or air collection on gold traps (Maserti and Ferrara, 1991) exhibited that the mercury levels measured in the atmosphere decrease rapidly a few hundreds meters from the plant. It appears also that background values around 3-5 $\mathrm{ng} \mathrm{m}^{-3}$ are reached in the vicinity $(1 \sim 2 \mathrm{~km})$ of the plant. Hence, it appears that high TGM values were recorded from time to time reflecting the influence of local anthropogenic sources. However, as regarding the entire set of data, our measurement site seems not to be heavily polluted in comparison with previous studies in urban areas showing higher mean TGM values (e.g. mean TGM 10 ng m ${ }^{-3}$, Fukuzaki et al., 1986; 
Kim and Kim, 2000; Tan et al., 2000). Moreover, since the spring campaign was hardly influenced by local anthropogenic sources (see discussion in paragraph 3.2), the mean TGM value of $1.9 \mathrm{ng} \mathrm{m}^{-3}$ is in very good agreement with values measured during the MOE/MAMCS campaign performed in 1998-1999 (Wängberg et al., 2001).

As regarding short-term variability, we tried to give a careful interpretation of this data. First, due to the limitation of our seasonal database and because of the strong variability of these data due to the influence of local anthropogenic sources, it is difficult to address a precise analysis. Then, trends presented here may reflect the temporal variations of meteorological parameters and also temporal variation in emissions. Indeed there are periods clearly identified (see paragraph 3.2) when an exceptional windy period is affecting significantly TGM data. Concerning the temporal variations in emissions, we established that the main sources around this site were the waste incinerator and the chlor-alkali plant. The other sources were considered as minor sources. Then, sources suspected to be highly variable in emission (such as heating for residential facilities) were supposed not to influence the short-term trends as a result of their minor importance in emission. According to the activity of the chlor-alkali plant and the waste incinerator, we were convinced that their productions remain constant during periods longer than one day. However, a diurnal variation of emission from the chlor-alkali plant may happen and will be discuss after.

According to the mean seasonal TGM concentration, TGM is significantly higher in fall than respectively in summer and winter whereas the mean concentration is lower in spring. Many authors reported various pattern in TGM concentration seasonal variation. Higher concentrations were often observed in winter (Lindqvist, 1991; Kim and Kim, 2000; Poissant, 2000). Our data do not show such a trend suggesting that heating for residential facilities may not represent a significant source of mercury in Champ sur Drac. Influence of such a source may also be hidden by another stronger anthropogenic contribution. Nevertheless, as our data are recorded on about 10 
days campaigns in each season, they cannot be significant as a real seasonal trend. Particular meteorological condition and especially atmospheric vertical distribution may influence them.

To elucidate any diurnal pattern within the data, we divided the data both seasonally and diurnally. The diurnal variability is displayed on a ratio scale, calculated as deviation from the mean concentration in figure 4 . We are aware of the difficulty to reveal a clear diurnal pattern for a site under obvious anthropogenic disturbance. However some phenomenon may be worthwhile to be discuss. In fall, winter and summer, an increase of TGM with the sunset seems to occur. We noticed that in this particular case TGM correlated better with the increase of temperature than with solar irradiation. This fact is clearly illustrated in summer when the TGM concentration increases rapidly concurrently with the first hot hours of the day. We speculated that it could be an illustration of both emission and reemission processes. On one hand it could reflect the volatility of many $\mathrm{Hg}$ species (mostly elemental mercury) emitted from natural areas around our site (Lindberg et al., 1991). On the other hand reemission of $\mathrm{Hg}$ species previously deposited is likely to occur. Therefore, temperature and solar irradiation could be two parameters affecting these processes. An increasing temperature and solar irradiation could activate and dissociate divalent mercury complexes through photoreduction reactions (Lindqvist, 1991). Then, emission processes could be accelerated as the temperature increases. However this is not consistent with midday measurements that should show highest values. Undoubtedly, emission and reemission processes provide a part of the TGM signal, however a clear identification is not achievable owing to the proximity of anthropogenic sources.

We sometimes observed high $\mathrm{Hg}$ concentration during the night time. It may represent an influence of nocturnal boundary layers form (Lee et al., 1998), trapping TGM near the surface. As focusing more in detail on night time data, during these events low wind speed and declining air temperature were observed. As Schmolke (1999) suggests, TGM concentration may increase as a result of low air-mass exchange and mixing. Thus it may indicate a local source for atmospheric mercury. Therefore, we cannot exclude the hypothesis of higher mercury emission from the chloralkali plant during the night. Because of the lower cost of electricity during the night, the chlor- 
alkali plant may increase its chlorine production and in this way the amount of $\mathrm{Hg}$ released. A previous study performed in a European chlor-alkali complex has also pointed out this phenomenon (Ferrara et al., 1992). However, this interpretation of seasonal and diurnal TGM variability may be misleading as the hourly mean have been calculated for a modest number of values (roughly 40 values for each hourly mean). Therefore, as a result of the high amplitude of TGM values on a 10days period, the confidence interval for mean is sometimes too large in order to deal with a significant interpretation.

\subsection{Influence of anthropogenic sources}

Primary, we attempted to give an assessment of potential mercury sources in the area of Champ/Drac. First, we had to deal with the chlor-alkali plant located in the vicinity of our measurement site. $155,000 \mathrm{t}$ of chlorine are produced yearly in this plant. According to several authors, mercury emission factors for chlor-alkali plants are in the range 1.4-5.3 $\mathrm{g} \mathrm{t}^{-1}$ of chlorine (Pacyna and Münch, 1991; Ferrara et al., 1992; US EPA, 1997; Mukherjee et al., 2000). Adopting an emission factor of $\sim 4 \mathrm{~g} \mathrm{t}^{-1}$, reported by Ferrara et al. (1992) for a similar plant, this chlor-alkali plant may release about $\sim 620 \mathrm{~kg} \mathrm{y}^{-1}$ of $\mathrm{Hg}$ into the atmosphere. Taking into account emission factors available in the literature and mentioned above, the range of emission would be $220-820 \mathrm{~kg}$ $\mathrm{y}^{-1}$. Concerning the municipal waste incinerator in Grenoble, we calculated that $\sim 280 \mathrm{~kg}$ of $\mathrm{Hg}$ may be injected per year in the atmosphere. This estimation is based on an emission factor of $2 \mathrm{~g} \mathrm{t}^{-1}$ of waste burned (Bouscaren and Houllier, 1986) and a total mass of 140,000 t of waste burned in 1999. As the chemical composition of municipal refuse and the emission control technique vary from an incinerator to another, it is difficult to adopt a global emission factor. We have chosen an emission factor, which is thought to correspond better to this incinerator. This emission factor is in agreement

with those reported in the literature, i.e. in the range 0.3-9 $\mathrm{g} \mathrm{t}^{-1}$ (Pacyna and Münch, 1991; Hester, 1994; Pirrone et al., 1996; US EPA, 1997) leading to a wide range of emission between 40 and 
$1,260 \mathrm{~kg} \mathrm{y}^{-1}$. Nevertheless, mercury emissions are probably underestimated while medical wastes are also burned in this incinerator. Indeed the $\mathrm{Hg}$ concentrations in medical wastes may be 10 to 50 fold higher (Pirrone et al., 1996) than that for municipal wastes. The heating company of Grenoble uses coal, oil, natural gas, wastes and wood as fuels. We estimated that this boiler may emit $\sim 11 \mathrm{~kg}$ $\mathrm{y}^{-1}$ of mercury. We had access to information concerning the crematorium of Grenoble. With an emission factor of $\sim 3 \mathrm{~g} /$ body (OSPAR, 2000), its contribution was found to be approximately $6 \mathrm{~kg}$ per year.

In order to examine the influence of anthropogenic sources on our measurement site, we sorted in figure $5 \mathrm{TGM}$ concentration above $10 \mathrm{ng} \mathrm{m}^{-3}$ related to wind direction. We have chosen to keep wind direction values that wind vector component should be at least $1 \mathrm{~m} \mathrm{~s}^{-1}$. Most of the TGM peaks occurred under north-northwest or north wind condition. This wind direction corresponds to air masses travelling over industries located at the north of our site and also over the city of Grenoble. Thus mercury is probably generated by local point sources in Champ sur Drac such as the chlor-alkali plant and others chemical industries using fuel combustion and also by Grenoble sources included waste incinerator and heating company.

As discussed earlier the TGM concentration was lower in spring than in all other season. It appears clearly that the spring monitoring period was quite unusual (Fig. 6). We identified 3 windy periods (period 1,2 and 3, see Fig 6) lasting approximately one day. As a result of a continuous wind, the accumulation of trace gases emitted by local sources as $\mathrm{SO}_{2}$, NO and TGM in the atmosphere was less efficient. Between these periods the wind speed was weak and we recorded high TGM values attributed to local anthropogenic sources. Indeed during the windy periods, the site was exposed to air masses coming mainly from the South. This area is a mountainous region where no important sources of mercury were identified. Consequently air parcels from the south are thought to be clean in mercury. Hence, the impact of local anthropogenic sources seems to be a factor affecting significantly TGM concentration in the air of Champ sur Drac. 
As we focused more in details on TGM and $\mathrm{SO}_{2}$ data, we observed the existence of similar variation between TGM and $\mathrm{SO}_{2}$ concentration. These similarities between TGM and $\mathrm{SO}_{2}$ peaks are especially well illustrated during the summer campaign (Fig. 7). The correlation coefficient for this period is $\mathrm{R}^{2}=0.35(\mathrm{~N}=150)$. It might suggest that some fuel combustions contribute to TGM signal. However this relationship is weak and combustion sources cannot be discriminated because there are events when TGM follows the concentration of $\mathrm{SO}_{2}$ quite similarly in time, but it also exists $\mathrm{SO}_{2}$ concentration peaks without corresponding increase of TGM. Combustions around Champ sur Drac may provide a part of atmospheric mercury signal. Nevertheless, wind direction dependence of some high TGM values and occurrence of TGM peaks that cannot be explained by closest combustion sources, indicate a mixture of pollution from the chlor alkali plant and the waste incinerator.

\section{Conclusions}

The high variability of TGM values is the first clear evidence of the influence of local anthropogenic sources. We estimated that the main local anthropogenic sources were the chloralkali plant and the waste incinerator (we speculated a total amount of $\sim 900 \mathrm{~kg} \mathrm{Hg}$ emitted per year). A similarity between $\mathrm{SO}_{2}$ and TGM concentrations profiles was sometimes observed that may indicate common sources.

Relationship between emission sources north of the site and wind direction was clearly identified. Most of high TGM values were observed concurrently with a north wind. Moreover during the spring measurement campaign, when the wind was stronger and/or from the south (where no Hg sources were identified), mean TGM concentration reached background values of 1.9 $\operatorname{ng~} \mathrm{m}^{-3}$ 
For the first time, an extended TGM database has been constituted in France. Since these data are scarce in France, and in order to develop for instance atmospheric transport models in Europe, such database are clearly needed.

\section{Acknowledgements}

This work has been financially supported by the Centre National de la Recherche Scientifique (CNRS, France) in the frame of A.T.I. (Action Thématique Innovante 1999).

We would like to thank the AS.CO.P.A.R.G. (ASsociation pour le COntrôle et la Prévention de l'Air dans la Région Grenobloise) for their technical support. We also thank Grenoble Alpes Métropole (Athanor, La Compagnie de Chauffage de Grenoble) and Atofina for their help for emission data collection. 


\section{Literature cited}

Bouscaren R, Houllier C. Réduction des émissions de métaux lourds et de poussières, Incinération des déchets. CITEPA, France, 1986.

CITEPA. Métaux toxiques dans l'environnement, personal communication, 2000.

Ebinghaus R, Jennings SG, Schroeder WH, Berg T, Donaghy T, Guentzel J, Kenny C, Kock HH, Kvietkus K, Landing W, Muhleck T, Munthe J, Prestbo EM, Schneeberger D, Slemr F, Sommar J, Urba A, Wallschlager D, Xiao Z. International field intercomparison measurements of atmospheric mercury species at Mace Head, Ireland. Atmos Environ $1999 ; 33$ (18):3063-3073.

Ebinghaus R, Slemr F. Aircraft measurements of atmospheric mercury over southern and eastern Germany. Atmos Environ 2000;34:895-903.

Ferrara R, Maserti BE, Edner H, Ragnarson P, Svanberg S, Wallinder E. Mercury emissions into the atmosphere from a chlor-alkali complex measured with the LIDAR technique. Atmos Environ 1992;26A:1253-1258.

Ferrari CP, Dommergue A, Veysseyre A, Planchon F, Boutron, CF. Mercury speciation in the French seasonal snow cover. Sci Total Environ 2001, in press.

Ferrari CP, Moreau AL, Boutron CF. Clean conditions for the determination of ultra-low levels of mercury in ice and snow samples. Fres J Anal Chem 2000;366:433-437.

Fukuzaki, N., Tamura, R., Hirano, Y., Mizushima, Y., 1986. Mercury emission from a cement factory and its influence on the environment. Atmospheric Environment 20, 2291-2299.

Hester RE. Waste Incineration and The Environment. Hester RE, Harrison RM, Royal Society of Chemistry, Letchworth, 1994, pp.27-47.

Kim K-H, Kim M-Y. The effects of anthropogenic sources on temporal distribution characteristics of total gaseous mercury in Korea. Atmos Environ 2000;34(20):3337-3347. 
Lee DS, Dollard GJ, Pepler S. Gas-phase mercury in the atmosphere of the United Kingdom. Atmos Environ 1998;32:855-864.

Lin C-J, Pehkonen SO. The chemistry of atmospheric mercury: a review. Atmos Environ 1999;33:2067-2079.

Lindberg SE, Stratton WJ. Atmospheric mercury speciation: concentrations and behaviour of reactive gaseous mercury in ambient air. Environ Sci Technol 1998;32:49-57.

Lindberg SE, Turner RR, Meyers TP, Taylor Jr. GE, Schroeder WH. Atmospheric concentrations and deposition of $\mathrm{Hg}$ to a deciduous forest at Walker Branch Watershed, Tennessee, USA. Water Air Soil Pollut 1991;56:577-594.

Lindberg SE, Stratton WJ. Atmospheric mercury speciation: concentrations and behaviour of reactive gaseous mercury in ambient air. Environ Sci Technol 1998;32:49-57.

Lindqvist O. Mercury in the Swedish environment. Water Air Soil Pollut 1991;55:1-44.

Lindqvist O, Rodhe H. Atmospheric mercury-a review. Tellus 1985;37B:136-159.

Maserti BE, Ferrara R. Mercury in plants, soil and atmosphere near a chlor-alkali complex. Water Air Soil Pollut 1991;56:15-20.

Mason RP, Fitzgerald WF, Morel FMM. The biogeochemical cycling of elemental mercury : anthropogenic influences. Geochim Cosmochim Acta 1994;58(15):3191-3198.

Mukherjee AB, Melanen M, Ekqvist M, Verta M. Assessment of atmospheric mercury emissions in Finland. Sci Total Environ 2000;259 (1-3):73-83.

Munthe J, McElroy WJ. Some aqueous reactions of potential importance in the atmospheric chemistry of mercury. Atmos Environ 1992;26A(4):553-557.

Munthe J, Wängberg I, Pirrone N, Iverfeldt A, Ferrara R, Ebinghaus R, Feng X, Garfeldt K, Keeler G, Lanzillotta E, Lindberg SE, Lu JY, Mamane Y, Prestbo E, Schmolke SR, Schroeder WH, Sommar J, Sprovieri F, Stevens RK, Stratton WJ, Tuncel G, Urba A. Intercomparison of methods for sampling and analysis of atmospheric mercury species. Atmos Environ 2001;35(18):3007-3017. 
OSPAR. Background Document on Mercury and Organic Mercury Compounds. OSPAR Commission, London, 2000.

Pacyna JM. Toxic metals in the atmosphere. Nriagu JO, Davidson CI, Wiley-Interscience, NewYork, 1986, pp 1-33.

Pacyna JM, Münch J. Anthropogenic mercury emission in Europe. Water Air Soil Pollut $1991 ; 56: 51-61$.

Pécheyran C, Lalère B, Donard OFX. Volatile metal and metalloid species $(\mathrm{Pb}, \mathrm{Hg}$, Se) in a European urban atmosphere (Bordeaux, France). Environ Sci Technol 2000;34:27-32.

Pirrone N, Keeler GJ, Nriagu JO. Regional differences in worldwide emissions of mercury to the atmosphere. Atmos Environ 1996;30:2981-2987.

Poissant L. Field observation of total gaseous mercury behaviour: interactions with ozone concentrations and water vapour mixing ratio at a rural site. Water Air Soil Pollut 1997;97:341-353.

Poissant L. Total gaseous mercury in Quebec(Canada) in 1998. Sci Total Environ 2000;259 (13):191-201.

Schroeder WH, Munthe J. Atmospheric mercury - An overview. Atmos Environ 1998;32 (5):809822.

Schmolke SR, Schroeder WH, Kock HH, Schneeberger D, Munthe J, Ebinghaus R. Simultaneous measurements of total gaseous mercury at four sites on a $800 \mathrm{~km}$ transect: spatial distribution and short-time variability of total gaseous mercury over central Europe. Atmos Environ 1999;33 (11):1725-1733.

Slemr F, Scheel HE. Trends in atmospheric mercury concentrations at the summit of the Wank mountain, southern Germany. Atmos Environ 1998;32 (5):845-853.

Slemr F, Schuster G, Seiler W. Distribution, speciation, and budget of atmospheric mercury. J Atmos Chem 1985;3:407-434. 
Tokos JJS, Hall B, Calhoun JA, Prestbo EM. Homogeneous gas-phase reaction of $\mathrm{Hg}^{\circ}$ with $\mathrm{H}_{2} \mathrm{O}_{2}$, $\mathrm{O}_{3}, \mathrm{CH}_{3} \mathrm{I}$, and $\left(\mathrm{CH}_{3}\right)_{2} \mathrm{~S}$ : implications for atmospheric $\mathrm{Hg}$ cycling. Atmos Environ 1998;32 (5):823-827.

Urba A, Kvietkus K, Marks R. Gas-phase mercury in the atmosphere over the southern Baltic Sea coast. Sci Total Environ 2000;259 (1-3):203-210.

Urba A, Kvietkus K, Sakalys J, Xiao Z, Lindqvist O. A new sensitive and portable mercury vapor analyzer GARDIS-1A. Water Air Soil Pollut 1995;80:1305-1309.

US EPA. Mercury Study Report to Congress. EPA-425/R-97-003, Office of Air Quality Planning and Standards, Office of Research and Development, US Government Printing Office, Washington, DC, December 1997.

Wängberg I, Munthe J, Pirrone N, Iverfeld A, Bahlman E, Costa P, Ebinghaus R, Feng X, Ferrara R, Gardfeldt K, Koch H, Lanzillotta E, Mamane Y, Mas F, Melamed E, Osnat Y, Prestbo E, Sommar J, Schmolke S, Spain G, Sprovieri F, Tuncel G. Atmospheric mercury distribution in Northern Europe and in the Mediterranean region. Atmos Environ 2001;35(17):3019-3025. 


\section{Figure captions}

Figure 1: Map of Grenoble area located in the south east of France.

Figure 2: Sampling site location.

Figure 3: Temporal variability of TGM (15 minutes data) at Champ sur Drac in 1999-2000.

Figure 4: Diurnal variability of TGM, (a) in fall, (b) in winter, (c) in spring, (d) in summer, presented on a ratio scale, calculated as deviation from the mean.

Figure 5: Gaseous mercury concentration vs. wind direction. Concentration scale starts from $10 \mathrm{ng}$ $\mathrm{m}^{-3}$.

Figure 6: TGM concentration and wind speed measured from 10 to 20 April 2000 (Spring campaign)

Figure 7: Variations of TGM and $\mathrm{SO}_{2}$ concentrations during summer 2000 (hourly mean). 
Table 1: Statistical summary of TGM data at Champ sur Drac in 1999-2000.

\begin{tabular}{ccccccccc}
\hline \multirow{2}{*}{ Season } & \multicolumn{7}{c}{ PGM $\left(\mathrm{ng} \mathrm{m}^{-3}\right)$} \\
\cline { 3 - 8 } & Period & Mean & S.D. & Min. & $\begin{array}{c}25 \% \\
\text { percentile }\end{array}$ & Median & $\begin{array}{c}75 \% \\
\text { percentile }\end{array}$ & Max. \\
\hline Fall & $11 / 04 / 99-11 / 16 / 99$ & 4,8 & 4,0 & 0,5 & 2,1 & 3,1 & 6,3 & 26,9 \\
Winter & $01 / 12 / 00-01 / 24 / 00$ & 3,1 & 2,4 & 0,1 & 1,3 & 2,8 & 4,6 & 16,1 \\
Spring & $04 / 10 / 00-04 / 20 / 00$ & 1,9 & 2,3 & 0,2 & 0,6 & 1,0 & 2,3 & 17,3 \\
Summer & $07 / 17 / 00-07 / 31 / 00$ & 3,7 & 4,7 & 0,1 & 1,0 & 2,1 & 4,5 & 37,1 \\
Overall & & 3,4 & 3,6 & 0,1 & 1,1 & 2,3 & 4,4 & 37,1 \\
\hline
\end{tabular}


FIGURE 1

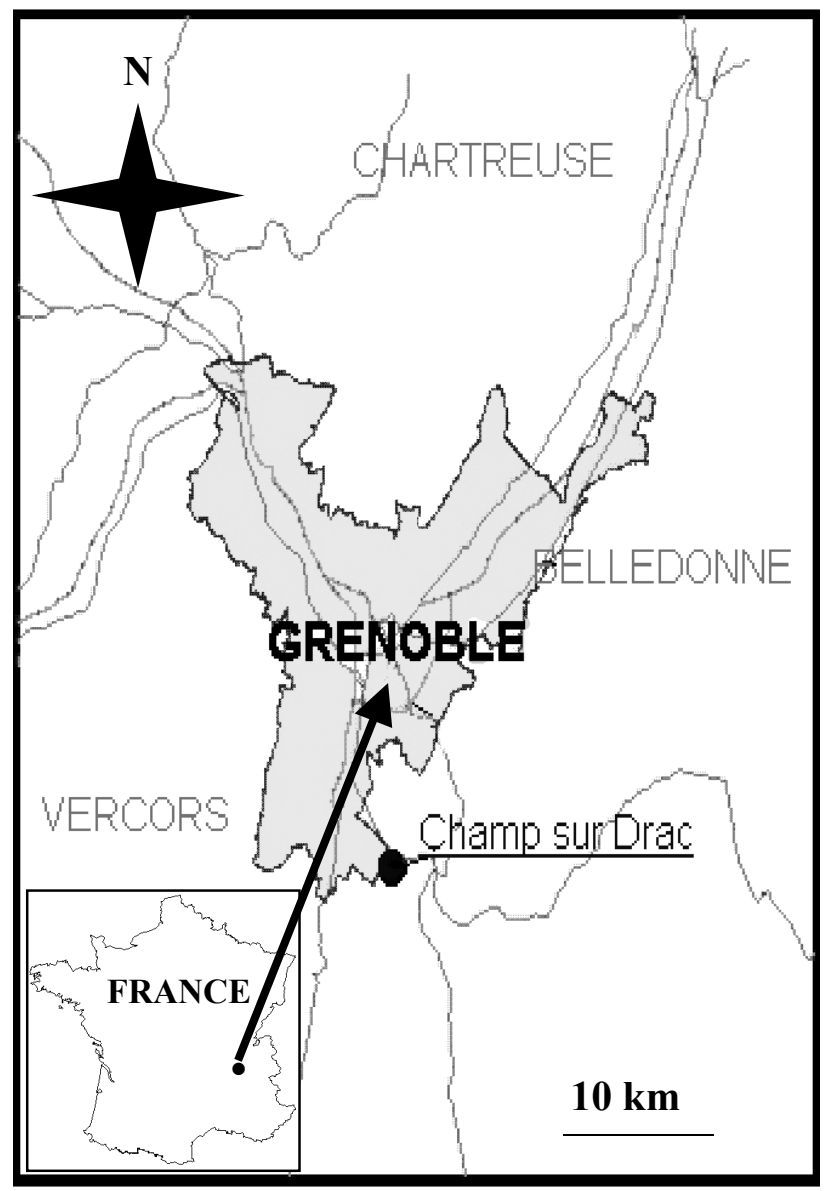


FIGURE 2

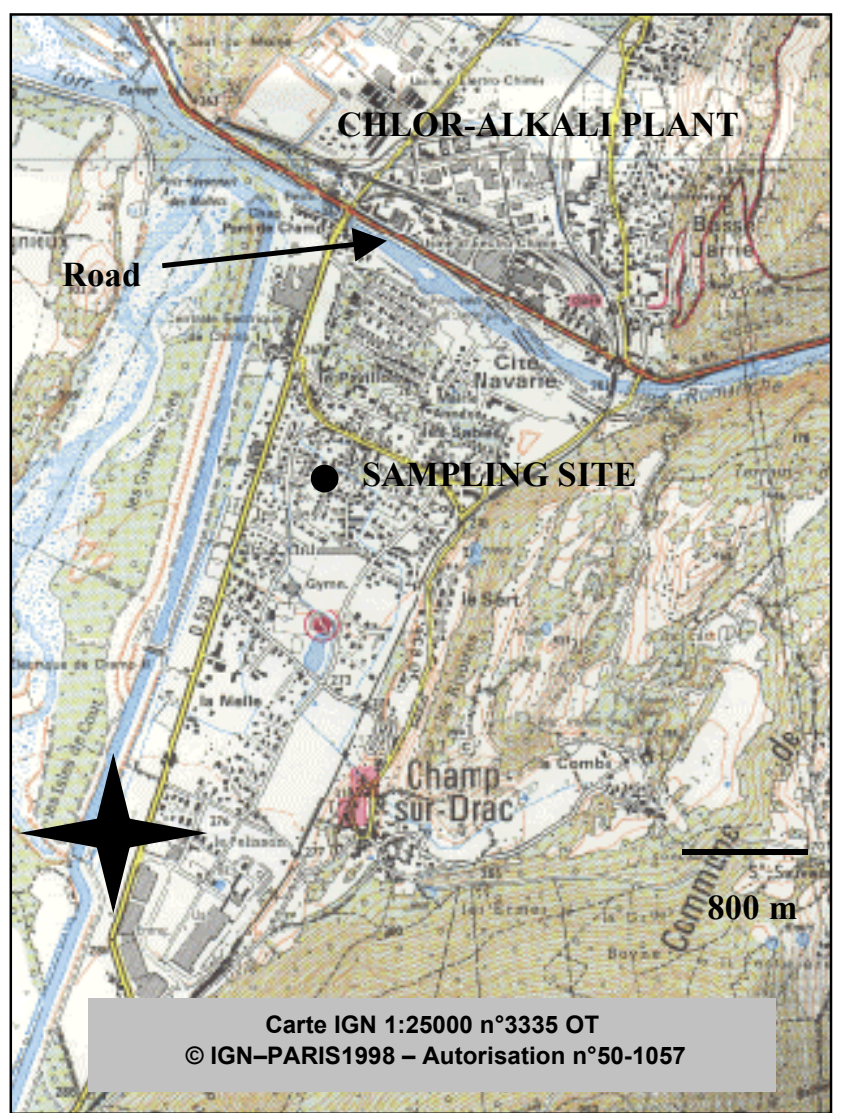




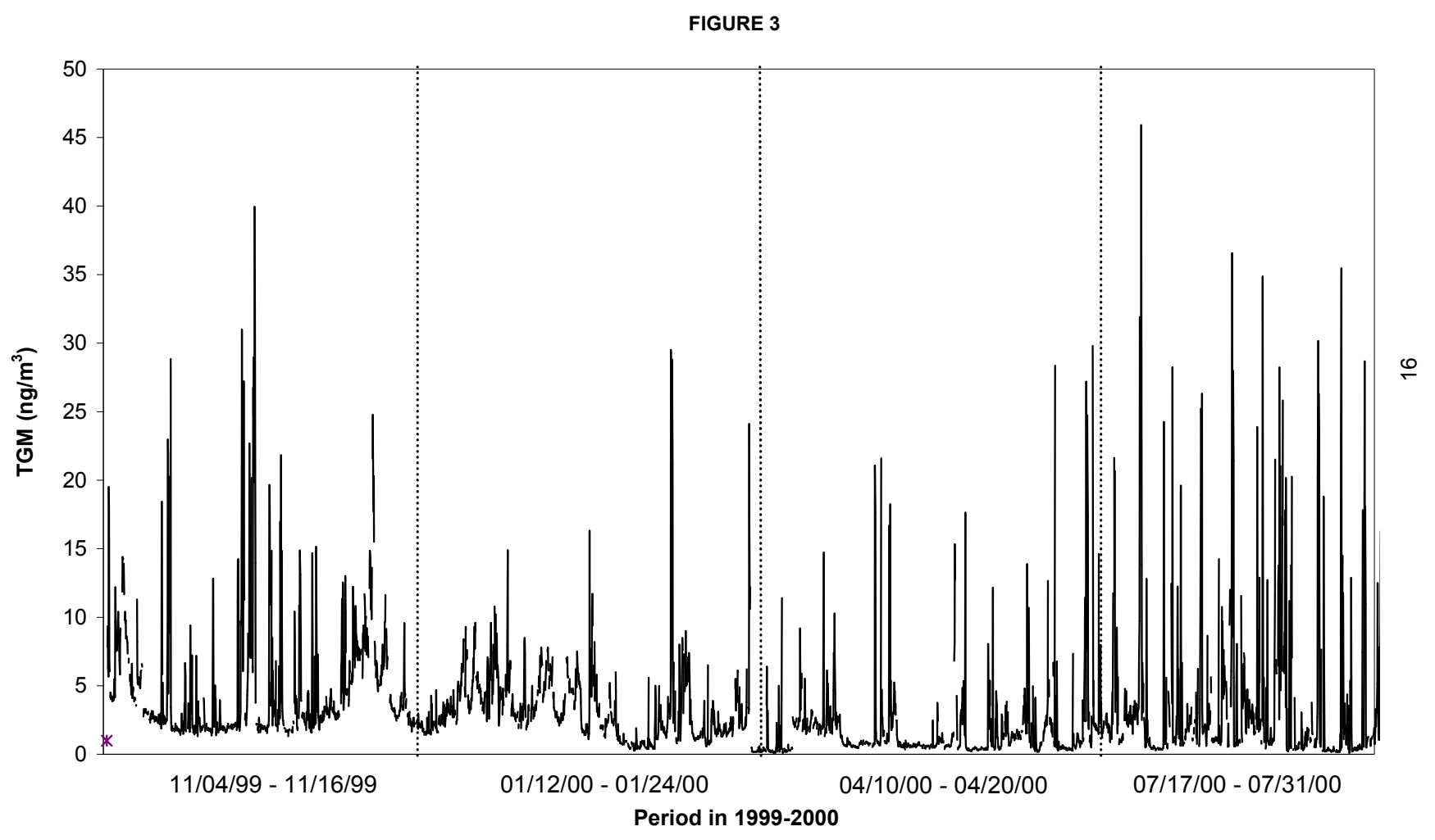


FIGURE 4

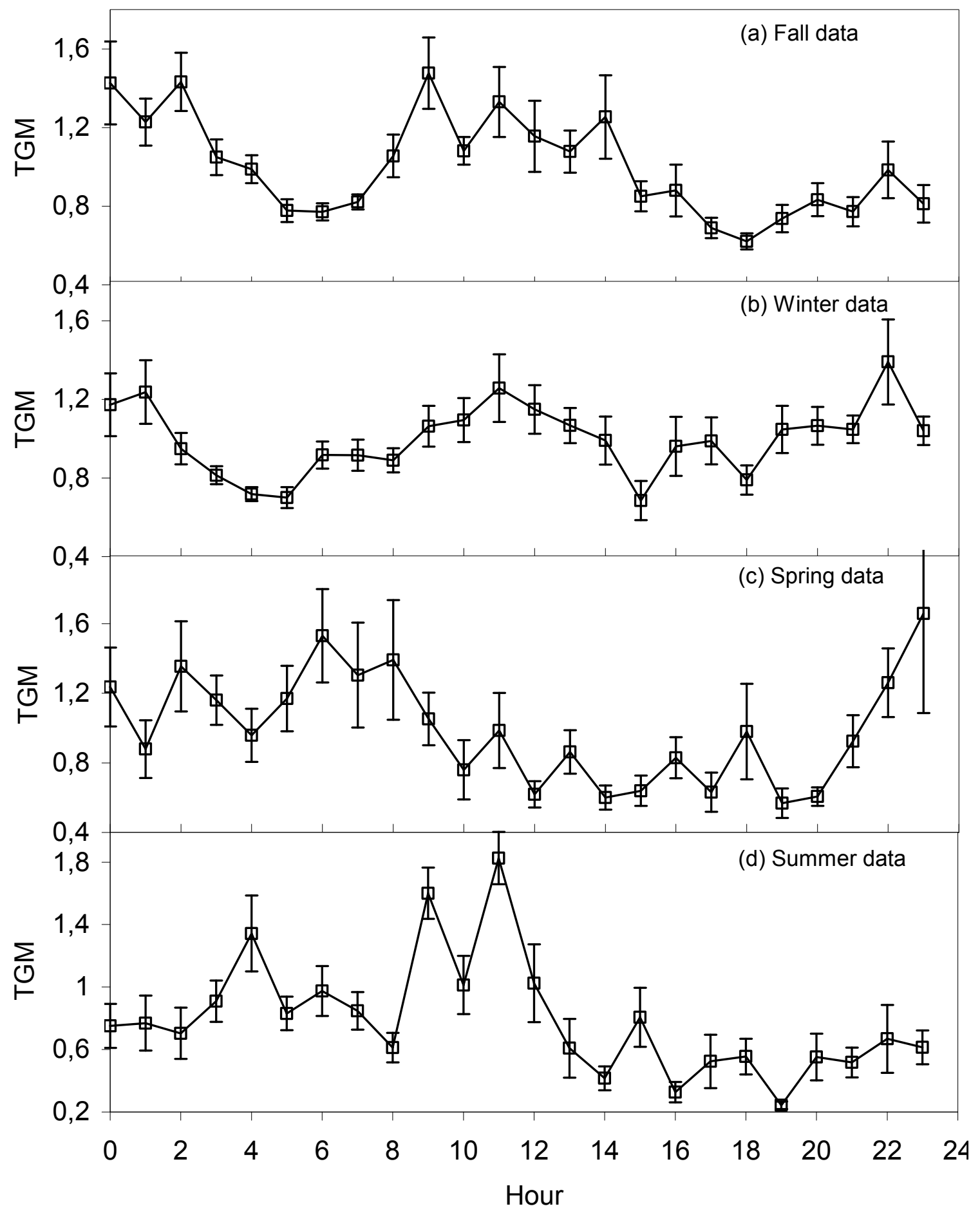



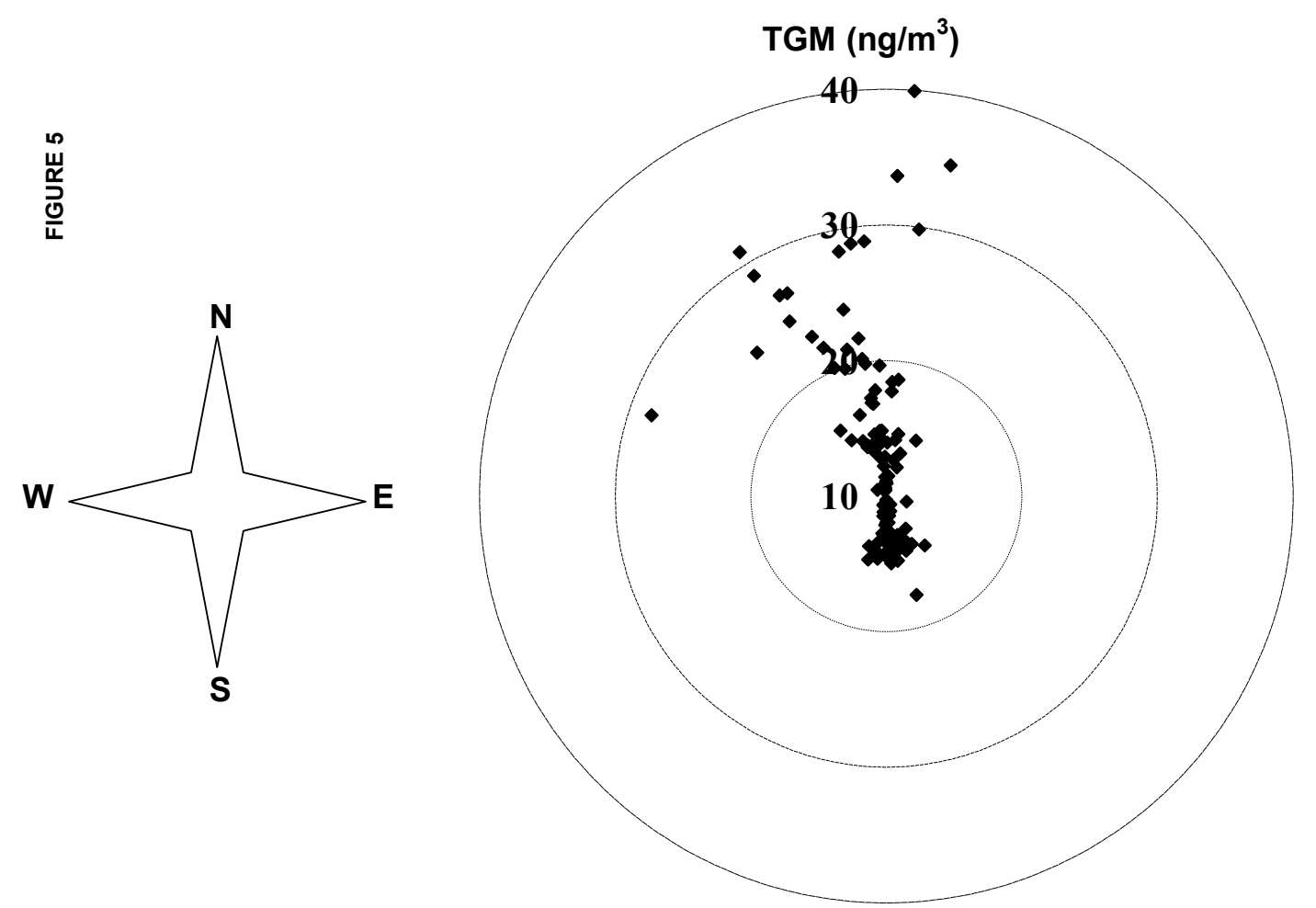


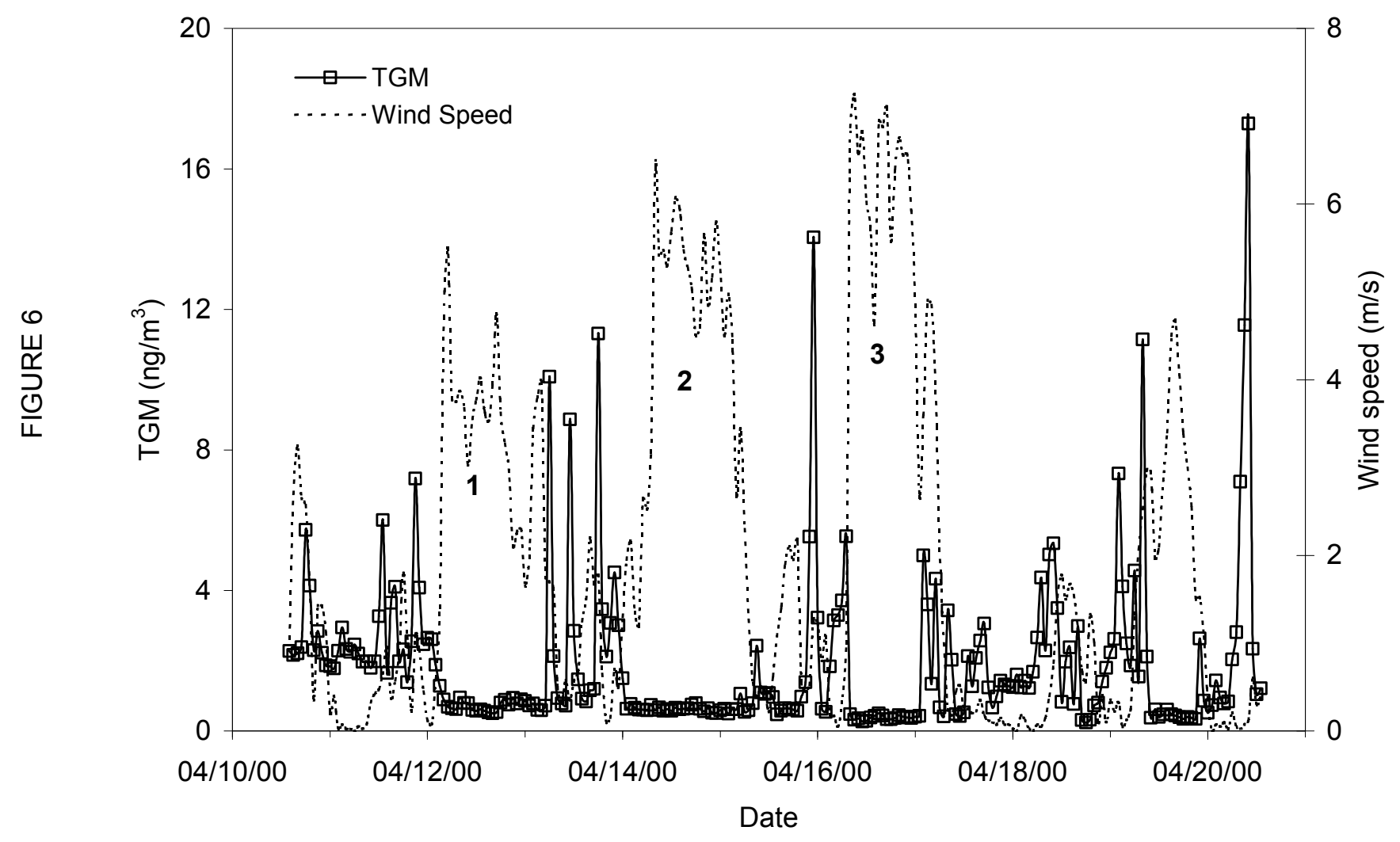


Figure 7

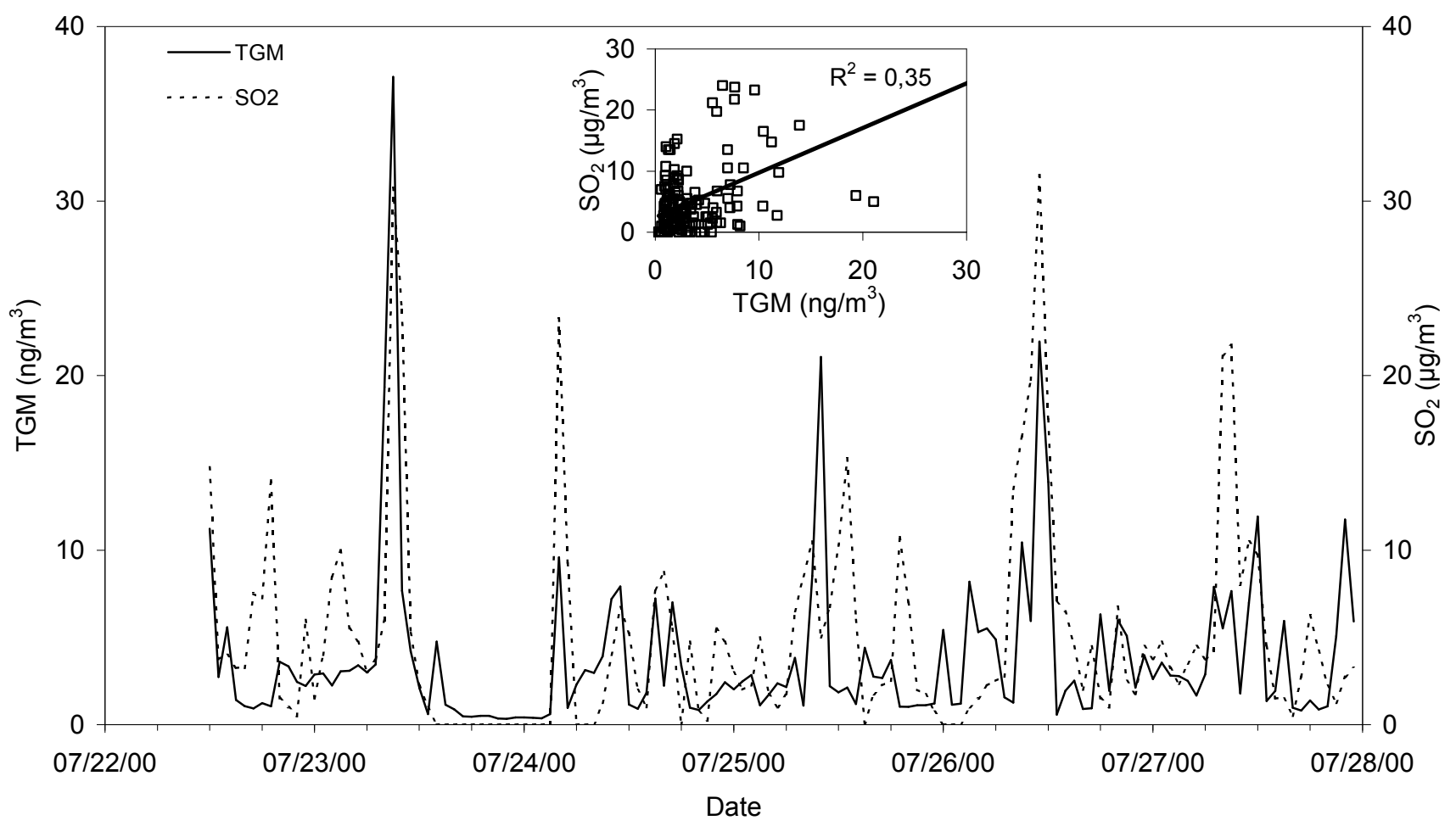

